\title{
Journalistic Education: Conceptualization and Media Competences
}

\author{
Zalina Feodorovna Khubetsova
}

Sergey Grigorievich Korkonosenko

Igor Nicolaevich Blokhin

Saint Petersburg State University, Russia, 199034, Saint Petersburg, Universitetskaya Quay, House 7-9

\section{Doi:10.5901/mjss.2015.v6n3s3p107}

\section{Abstract}

The paper considers tendencies of journalistic education development in higher education institutions under conditions of journalist profession transformation caused by increasing influence of social and technology factors. Based on the comparative analysis of reorganization process of leading Russian and German centers of higher professional educations of journalists conclusions of blurring professional journalistic education subject definiteness, technocratization, which aggravates contradictions between forms and content of teaching process, and overvaluation of multimedia factor, which often replaces classification universality with, are drawn. The paper's authors consider the change of base model of professional education focused on traditional competences in the area of media works creation the principal direction of overcoming negative trends in institutional training of journalists. A new competence-based model should reflect principal changes of journalistic working conditions: increase in information scope requiring for processing; increase in operational efficiency; transformation of technological cycle of media production and media convergence; appearance of new interactive opportunities of interaction with audience and means of journalist's communication skills realization. In order to be successful on the media market the modern journalist should know ever-changing information legislation and be able to apply corresponding knowledge in practice; to master defense skills against aggressive media influence, media violence and manipulations and initiation of communication in interactive environment; to properly perceive and understand the reality around and consequently create media texts adapted to the needs and capacities of different publics. The essential condition for competence-based model of students' training is stability of educational process ideology based on acknowledgement of journalist's high social and occupational status.

Keywords: journalism, journalistic education, profession, media competences, professional education model.

\section{Introduction}

Technologic progress became one of main factors of the world media system transformation at the turn of the $20^{\text {th }}$ century. Shift to digital format of broadcasting, formation of the global information space, convergence of information media, appearance of new opportunities relating to development of the Internet, cellular and satellite communication this is a short list of important changes that defined the nature of transformation of journalism social institution in the new century. The notion of Mediapolis as a fundamentally new phenomenon in the civilization development has come into international scientific use (Inkinen S., 1999; Rodgers S., Barnett C. \& Cochrane A., 2008; Silverstone R., 2007). Development spurt of media information technologies gave rise to unprecedented quality of life of the human and society (media life), which is characterized by universal availability of media resources and freedom of their use to produce individual texts, blogs, websites, web publications, etc.

In social and humanitarian dimension such in-depth metamorphoses are estimated as apparent benefits. They mark a new breakthrough to personal freedom in mass information sphere, sharply diminishing degree of individual's dependence on producers' dictate and message distributors, extend the frontiers of choice, increasing person's status and measure of self-respect, etc.

At the same time, multiple increase in the number of mass information producers impose threats on the existence of journalistic profession as a specialized activity. At least there are reasons to reflect on its content and criteria of estimation. A set of these criteria can scarcely be correlated to formal registration of mass media, which is put an emphasis on in national and international regulatory documents. Today a "registered" dilettant is not less widespread phenomenon than "non-system" amateurs calling themselves journalists. Successive development of ideas of limitless extension of journalism field inevitably results in a currently popular conclusion-sentence: "Journalism has died!..." 
(Miroshnichenko A., 2011; Luksha P. et al., 2014; Jarvis J., 2009; Shirky C., 2009).

The authors of this paper take the direct opposite view, however we refrain from discussions concerning this matter. In this case it's important that the change of ideas of journalism is projected on understanding of journalistic education content and organization.

On the one hand, the conclusion on the "death" of journalism should be resulted in the appeal to eliminate the system of personnel training. However, critics of education usually keep from such radical statement of the problem. On the other hand, apologists of classical university system cannot but respond to doubts growing in society concerning the profession. Once again different solutions are possible - from the movement to content and structure amorphism to strictly technological education designed to provide graduates' conformity to paces and formula of technological progress in media area.

There's another possible solution. Current boom in amateurism in mass media practice, terminology, conceptual formations causes decisive strengthening of professionalism.

One of the most authoritative social thinkers and researchers of the modern world Manuel Castels comments the problem of modern journalist's professional training quality increase under the conditions of growing competition on the part of amateur journalists in the following way: Many media do not acknowledge civil journalism and consider it a danger. Others, which present the best part, much wiser and proficiently use advantages of civil journalists... To some extent journalists become more specialized analysts and can put information in a context. Civil journalists provide information, facts examination is editors office's task, and a specialized text, a context are still the patrimony of professional journalists. Thus, in point of fact it modernizes the role of professional journalists, and doesn't make it disappear... This role becomes more complicated than ever... and more interesting and requires for better training" (Castels M., 2012). Who else but pedagogical community needs to take care of the question of journalistic cadres' training quality increase.

Thus, the objective of our analysis consists in elaboration of principal approaches to professionalism criteria definition in the system of journalists' university education and description of a set of media competences, without which a modern graduate of higher education institution fails to successfully realize his professional activity.

\section{Methodology}

\subsection{Key issues of journalistic education}

"Obviously journalists shall remain journalists above all" (D'Inka W., 2004, p. 67), highly experienced German newsman Werner D'Inka assures, and this idea should be used as a basis of the search in education theory and practice. On the indirect analogy with consumer's market: the more blatant and numerous forgeries of famous brands, the more definite and strict standards of branded goods production should be. In case of journalistic education "branded goods" is a specialist, who cuts off any doubts concerning differences between amateurism and professionalism with his practice. It's also critical to him to realize and state these differences, in whatever way his business environment and its identification characteristics change over the course of time.

In our opinion, regarding journalistic education, rationality and technocracy are reasonable to the extent they subject to the ability to see and understand life in its more significant manifestations. Probably, university community won't conceive this message. But is there another fundamental educational research idea divining the future of journalistic education and expressed in a somewhat integral and consistent form? For a quite long time we have noticed that teaching of journalism has become actual, widespread practice in Russia and in the world at large. Over the last years the palette of journalistic education researches has significantly enriched oneself, several doctoral theses were passed in Russia (Raspopova, S.S, 2007; Fateeva I.A., 2008; Shesterkina L.P, 2011). Apparently, these are comforting turns for the better. However, we risk stating that the task of definition of the optimal model of journalists' institutional training is far from the solution.

For quite objective reasons instrumental motives in the ideology of journalists' training are main ones. It's sound to some extent since internationalization of science and scientific activity, exchange of scientific knowledge accumulated in the framework of national research institutions, cross-fertilization and organization of supernational research discourse, the need in updating the system of professional training - these are challenges of time, ignoring of which leads to lagging in the global scientific (and not only scientific) competition. However, in our opinion, reducing current paradigm of education to a set of pragmatic competences necessary for worker's competitive performance increase under the market conditions is wrong. Let's remember a number of qualification parameters included in regulatory documents (common for journalists, historians, physicist, and others): in educational standards of Bachelor's programs education outcomes are considered adopted knowledge, skills and abilities, and adopted competences. Creative thinking, and also necessary to 
the human abilities to act in a situation of uncertainty cannot be formed within the framework of adaptive strategy (Druzhilov S.A., 2012, p. 8).

Instrumental skills, if they aren't supported by fundamental pedagogical ideas, can be easily reformulated, combined with technologies of other professional fields, if not entirely changed. To train cadres for mass media is not a function, but only a progress, though some departments and faculties describe their purpose as training. Since the conceptual core of educational program has no sufficient firmness, it's subject to blurring and even dissolution in aggressive academic environment.

Recently journalistic by their origin training (and at the same time scientific) facilities change their priorities in organizing the system of education and teaching of journalism. This process is actively developed in Russian and abroad. It's accompanied by intense searches in education-related theory and methodology of researches in the area of journalism (Baran S.J. \& Davis D.K., 2012; Wahl-Jorgensen K. \& Hanitzsch Th., 2009, etc.).

\subsection{Reorganization of journalistic education in Russia}

In Russia journalism educational and research centers emerged from the interior of philological scientific educational structures for a long time have maintained close etymological ties with them. Philological and historical disciplines prevailed in curricula of journalists' training. As a rule, papers on journalism and philology were published in scientific issues in a common series, philology and journalism have a common code in the nomenclature of scientific qualification (10.00.00). Despite the fact that since 2001 in Russia qualification by the scientific qualification "journalism" began to be conferred not only regarding philological but political science, there were much less theses for academic degrees concerning political science than philological ones.

By 2010s the situation began to change. Hours dedicated to students' studies of journalism history and literary language basics were considerably cut, and positions of social humanities and communication disciplines were consolidated. Increase in significance of applied - mass communication - aspects of learners and studying journalistic practice led to mass renaming of faculties and departments of journalism. For example, in 2001 the journalism department of Chelyabinsk State University was transformed in the department of journalism and media education. In Far Eastern Federal University journalism underwent long evolution - from a division at philology faculty to independent faculty, subdivision of the Institute of mass communication and in 2011 with the creation of huge Far Eastern Federal University - to departments of mass communication with wide profile of educational activities.

Journalism traveled the same long distance in Kazan State (currently Privolzhsky Federal) University. From 1962 there was journalism division at the historical and philological department. In 1992 it was granted the status of independent faculty, and in 1994 when subdepartments of sociology and psychology were added to it, a new structural unit appeared - the faculty of journalism, sociology, and psychology. From 2003 the department continued its existence under the new name of the faculty of journalism and sociology. In 2012 the Institute of mass communications and social studies was established based on the faculty. Subsequently in 2014 it entered the Institute of social and philosophical studies and mass communications. Thus, according to the intention of university management the study and teaching of journalism in higher education institutions should be carried out in socially philosophical and mass communicative context.

The reorganization of the faculty of journalism of the St. Petersburg State University became a response to the increase in mass communicative aspect significance in studying and teaching journalism. From 1996 the faculty of journalism began to train public relations specialists, and from 2005 - advertising specialists. Extensive development of the scientific and educational direction "Advertising and public relations" met support in the form of specialized subdepartments establishing, attraction of new employees, introduction of a growing number of so-called communicative disciplines in journalists' curricula.

As mentioned above, such processes take place in many higher education institutions of Russia, and they are accompanied by growing anxiety of academic and professional journalistic community regarding incompatibility of qualitatively different directions of training under the same roof. In our opinion, this case clearly shows the false choice of base pedagogical ideology - focusing on communicativeness as an integrating feature of journalism, PR and advertising. Realization of this methodological mistake gave a momentum to division into two faculties - the faculty of journalism and the faculty of applied communications. In 2011 the "Higher School of Journalism and Mass Communications" Institute was established based on the 65-years faculty. The new structure allowed keeping the independent status of journalism, which it may loss over the course of time, preserving relative autonomy of different educational programs and at the same time it didn't destroy previously established administrative, cross-curriculum, scientific and research, and other relations. 


\subsection{Journalistic education in the FRG}

The similar situation of increase in mass communicative aspects significance in journalism studying and teaching takes place in a number of European countries, particularly, in the Federal Republic of Germany - a country with high scientific potential, always notable for fundamental nature of science and academicism of educational system. German experience is also interesting since it was the very standard that used Peter the Great as a basis for Russian system of professional education.

According to the tradition established in Germany, there are two main models of journalists' training - practical (short-term training in journalism schools along with the system of practical trainings under mass media editorial offices) and theoretic-practical (long-term training of journalists-practicians and journalism researches in universities). For obvious reasons we're mainly interested in the system of institutional training of journalists. Just as in Russia scientific research and teaching of journalism in higher education institutions was initially closely related to studying philological disciplines (Germanistics and literary studies) and theatre history (Frühbrodt L., 2010, s. 35).As late as in the middle of 1970s journalism was granted its academic status. For the first time journalism courses as individual educational and science disciplines (still strongly focused on practice) were taught to students at the universities of Dortmund and Munich, a bit later - in other higher education institutions of Germany. For a long time institutes of journalism or social journalism remained main structural subdivisions that trained journalists. As in Russia great attention in training specialists for mass media was paid to philological competences formation and studying features of individual journalistic works.

By 2000 academic journalism started its transformation. The majority of classical institutes of journalism and social journalism were converted into media and communication study centers. For example, training of journalists in Free University of Berlin is carried out by the Institute of social journalism and communications; in Ruhr University - Section of social journalism and communications; in the IImenau University of Technology- the Institute of Media and Communication science; in Leipzig University - the Institute of communications and media researches; in the University of Münster - the Institute of social journalism and communications; in the University of Regensburg - the Institute of information and media, language and culture, etc.

Only two higher education institutions of the FRG keep names traditional for the system of professional training of journalists. These are the Institute of journalism in the Technical university of Dortmund (which up to date has kept close relation with philology and enters the department of cultural studies) and the Institute of social journalism in the Johannes Gutenberg University of Mainz. However, even these higher education institutions that don't give way to reorganization sensitively respond to the needs of changing social environment. For example, the Johann Gutenberg University of Mainz offers to its students "unique diversity of opportunities for studying and researching by all main topic relating to media, journalism and communications" (cit. official site of the Institute of social journalism. Retrieved from: http://www.blogs.unimainz.de/ifp).

In addition to philological component a number of social and humanitarian disciplines were introduced in journalists' training programs. In many higher education institutions teaching becomes of more utilitarian nature, currently great attention is paid to technical and technological aspects of journalistic activity. For the purpose of strengthening relation with journalistic practice higher education institutions use new models of education. Some began to cooperate with journalism schools (for example, the Institute of media and communication science of Ludwig Maximilian University of Munich established journalism Master's program jointly with German school of journalism, the Hamburg University cooperates with media school); others include practical training in their educational programs (for example, Technical university of Dortmund or the Leipzig University).

Thus, nowadays about 20 higher education institutions implement about 500 programs of higher professional education on journalism conferring bachelor's, specialist's, master's degree of journalism; some universities provide an opportunity of gaining a degree after graduation of postgraduate courses and thesis defense. Describing qualitative characteristics of educational programs of German higher education, professor of the University of Applied Science Würzburg- Schweinfurt Lutz Frühbrodt states, "in the area of research of mass media, social journalism and communications theoretically oriented curricula still dominate in a quantitative way, however recently the number of practically oriented educational programs has been increased considerably" (Frühbrodt L., 2010, s. 38). Emerging role of technological component in mass media activity led to the higher demand in German higher educational institutions for educational programs of technological profile (such as media design, media management, mass media technology). Today previous analogues of programs are fleshed out with new - more mechanistic - content. It is worthy of note that in the majority of educational programs and courses the word "journalistics" was replaced with "journalism" that has a functionalistic touch. The reform of the system of higher journalistic education in the FRG was largely ignited by the Bologna process; as a result the academic world began to sharply criticize educational standards unification higher 
education institutions faced in its entirety in early 2000s.

One may suppose that detected features of journalistic education system development aren't of national, but supernational nature and reflect dominant world tendencies.

\section{Media Competency as an Objective Function of Education}

\subsection{Media competency: content and classification}

One of main requirements of modern mass media for the system of education relates to qualified specialists training in the area of media relations and processes. Student's competency consists of ability to create media texts, regulate communications, analyze mass communication, etc., i.e. the leading teaching task is to form to-be journalist's media competency. Media competency as an objective function of education is a complex of knowledge, skills and abilities, specific list of which depends on both level of education (from elementary to postgraduate) and its subject characteristics.

Diversity of concepts and approaches is caused by the presence of value content in both education in general and media education in particular. Given this, this content is interpreted by pedagogical science in different ways.

A number of European researchers suggest approaches to classification of media competence and media competency. For example, Masterman L. distinguishes three conceptual approaches: injection approach, media as a kind of popular art and media as a representation of the world through the system of symbols (Masterman L., 2001). French researchers Piette G. and Giroux L. distinguish seven concepts: concepts of "magic bullet" (same-name mass communication theory is taken as a basis), profit and benefit, development, settings of currents of thought, critical, semiotic, sociocultural (Piette G. \& Giroux L., 2001). Among main groups of media competences German scientists Aufenganger S. distinguishes protective, critical, practical, and anthropological ones (Aufenganger, 1999).

St. Petersburg researcher Kasumova E.V. develops anthropological approach to media education development (Kasumova E.V., 2014). She suggested the model of media competences based on personal claims "I can", "I'm able", "I know" and "I have a skill".

The group of "I can" claims allows estimating theoretical possibility of working with information, availability of information and technical means that provide its transfer: competences of receiving texts (base and computer literacy), its understanding (base literacy and text coding system basics), information transfer (availability of access to information distribution).

The group of "I'm able" claims describes base skills, which relate to experience of interaction with media, and their formation relates not only to the area of media education but the area of social experience in general: competences of understanding of the need in receiving text, voluntary or forced nature of such receiving, estimation of prerequisites, prejudices and others blockers of information, correlation of text information with data that a receiver already has, revaluation of received information when receiving new data, understanding of who and for what purpose created a text, what forces (of what entities) text's creator presents.

The group of "I know" claims characterizes person's knowledge in the area of working with media, allows defining degree of his actions' awareness and reflectivity: competences of information search, working with information resources, differentiation of methods and techniques used in a text, definition of actions in cases of illegal information or limited access to legal information, awareness of responsibility for information distribution.

The group of "I have a skill" claims reflects individual's practical skills in the area of working with media: competences of resources classification depending on information type, selection of media texts, definition of their genres, distinguishing of the main idea of a media message, information reliability estimate, selection of information from several variants.

\subsection{Regulatory and psychological media competences}

Approach to media competences analysis offered by Kasumova E.V. is closed to the model of media behaviour role analysis to the utmost. Thesis on the decisive role of person's media activity in the processes of selection, filtering, control, creation, structuring of information is the basis for this model. When analyzing the structure of media competence it's suggested to use two approaches: the analysis of person's interaction with media sphere and the role analysis of media behaviour. Person's interaction with media sphere is based on the processes of internal and external regulation of such relations. External regulation is the basis for distinguishing the group of regulatory media competences, which above all things include knowledge and skill to use information legislation provisions. In a specialized model of education regulatory competences forms the understanding of in what way mass communication is used for the purposes of social 
relations regulation.

The need in internal regulation (self-regulation) forms a complex of psychological media competences. They include defense skills against media influence, media violence and manipulations, and also skills to properly perceive and understand texts of media works. In particular, the role of psychological media competences involves person's opposition to intense concentration of personal data used to control population. Regulatory and psychological media competences are person's information security formation basis as a skill to provide security of his own information resources and flows, and also to stand against negative influence on psyche and individual consciousness.

Competences relating to person's degree of involvement in media sphere are distinguished based on the role analysis of media competences. They allow the person to approve himself as an independent ("integral") object, that defines attractiveness of media behaviour for the person in fact. In this case attitude to the person changes, he appears as a center of his own system of axiological world outlook coordinates.

Understanding of person's media behaviour takes place through information he consumes and through communication he enters, initiates or provokes. Person's behaviour in media sphere is estimated through media preferences and network routes. Niklas Luhmann states that "presence of "the human" is implied in all program area of communication media, - but ... as a social construct. This social construct... is necessary in the functional system of mass media in order to constantly and continuously expose itself to stimulations emanating from the prospect of biological and psychological external world of the person $\langle\ldots\rangle$ passions of billions of psychic events are translated into a form, which supposes its further use within mass media system and new psychic interpretation in a number of resulting differences" (Luhmann N., 2005, p. 129-130). Luhmann clearly makes the problem of understanding the person through media actual. It can be solved providing recognition of the principle of identity of media environment and the person existing in it.

The individual related to network media environment cognitively and mentally appears as a media person. According to Mansurova's definition, "media self-reflection and personal identity become the ontology of contemporary society existence, and an individual, who gained an unauthorized access to communication acquires the status of homo mediates" (Mansurova V.D., 2011, p. 8).

Thus, information and communication competences are distinguished in the structure of media competency. As types of activity in media sphere there are four variants of its possible manifestation: consumption, navigation, communication, and production. Certain type of role behaviour corresponds to each of distinguished types: consumer, navigator, communicator, and author (Modern Russian mediapolis, 2014, p. 220-226).

\subsection{Information competences}

Information competences pursue the aim of consumer's (general media competence) and navigator's (peculiar media competence) role models formation. Consumption is considered the beginning of feedback in the system of communication. Consumer's information competences involve skills and abilities of information search and navigation, analysis and critical reevaluation of media texts.

A person gains consumer's status "entering" media sphere, spending his time within. The subject of consumption in media sphere is amenities of information and communicative messages. "Nowadays it's not enough to inform to carry out communication not only because of ever growing number of messages and communication's requirement for its filtering but the emerging role of information receivers" (Volton, 2011, p. 6). Information consumer demonstrates the identity of subject and object interaction. The mechanism of identity consists in identification - the process of taking consumer's role indicated and defined by the message. Identification for consumer is a method of adoption of settings and values proposed by the message as one's own achievement.

According to Jaspers' Axial Age the phenomenon of communication is considered a person's inner metaphysical ability to discover other sense: "Ability to see and understand others helps to explain yourself to yourself, to overcome probable narrowness of each closed historicity, to make a jump afield" (Jaspers K., 1991, p. 49).

Navigator's task is to regulate information flows. The nature of his activity makes it possible to distinguish various types of navigation: information distribution through information and advertising agencies, mass media distribution, stimulation, sorting or blocking of information and communications, elimination or damage of information (hacking), etc. Navigators' competences' specific nature consist in the skill to determine media texts resources, their authors' interests and contexts, and also interpretation of media works and values distributed by media (critical autonomy function).

A worker of media sphere - an operator of perspectives, contexts and meanings - gains navigator's status. Social meaning of navigation in media sphere involves the organization of coexistence of ideas of the world, senses and values: "communication is not sharing the same views by individuals, but organization of coexistence of often contradictory ideas 
of the world. $<\ldots>$ Communication is teaching of coexistence in the world of information, where the issue of otherness is a central one" (Volton D., 2011, p. 33). Organization of communication and, consequently, teaching to coexistence is navigator's activity main principle.

Successful navigation as contexts and sense organization activity requires, on the one hand, for necessary level of education, from the other hand, - awareness of responsibility for one's activities consequences. Therefore, the role of journalists grows as communication navigators and information organizations.

\subsection{Communicative competences}

Communicative competences are distinguished based on the role behavior of communicators and authors. Communicators' activity leads to development of network structures similar to social structures. Networks appear based on the objective need for communication and solution of certain (specific) problems. Communicators' competences consist in abilities to interact using QMS and feedback skills, and functions - in initiating communications and producing messages.

Exchange is the basis of networks' formation. The concept of social exchange belongs to American researcher George Homans, who described social behaviour as exchange of activities that lead to rewards and expenses. Homans stated a number of propositions, which establish social exchange: impetus, value, deprivation-satiation, aggressionapproval, and rationality (Homans G., 1996). Description of human behaviour in Homans's theory became the starting point for exchange conception of American sociologist Peter Blau, who tried to understand social structure by means of analysis of processes regulating relations between individuals and groups (Blau P., 1994). Social exchange created social structures is formed in the form of social networks, which find "real" possibility for its functioning by means of computer technologies and the Internet. Norbert Bolz marks the role of networks both on a global basis and in a new quality of social differentiation: "Characteristic value of networks is.... not information processing, but creation of commonalities. As a result, nation as an instance causing identities increasingly looses its significance - for the benefit of globalizing, but also "tribilizing" forces" (Bolz N., 2011, p. 104).

Author's competences are based on person's creative, communicative skills. They are skills of self-expression, critical thinking, creation of media texts, selection of corresponding media channels to create and distribute media works, and attraction interested groups. The author created the second - subject to "certain conditions - reality, from the perspective of which common style of life appears as real reality (Luhmann N., 2005, p. 83). Author's status involved production of information, transformation of mundanity in an event. Author can appear as an "event's creator". Author blurs out distinctions between daily life's event in the real world and media sphere; for modern age such manifestation of author's role in the networks as bloggership is common.

\section{Conclusion}

Submission of journalistic education to various mergers and recombinations, which coincide with the theses of journalism's "death" equally disturb Russian and foreign specialists, who provide higher professional education of journalistic cadres. Journalists must remain journalists - it's established truth to us. But where we may find the way to its implementation in educational process? Inclination to technicism and exaggeration of multimedia factor nothing but peak contradictions between educational process forms and content.

As the analysis shows the solution is change of the basic model of journalistic professional education.

Firstly, training of specialists should be combined with editorial production, when teaching is carried out in parallel with professional journalistic work. Such modernization will allow education institutes to exercise system monitoring of changes in the world of mass information, shift in technological modes and to involve professional education in the processes of information changes management.

Secondly, universities should become the centers of innovation media production, correspondingly. It's possible providing adoption of special state programs or admission of higher education institutions in the business area of large media holdings.

Thirdly, principal changes of journalistic working conditions should be reflected in the system of education. In addition to traditional author's competences with regard to media works creation a modern journalist needs new skills and abilities: handling information and its organization, structuring and adaptation for various publics. Correspondingly, the basic mode of graduate's training should be focused on formation of at least four groups of competences. The first group is regulatory competences (knowledge and ability to use information legislation provisions). The second group is psychological media competences (defense skills against aggressive media influence, media violence and manipulations, 
and also skills to properly perceive and understand media texts). The third group is information competences necessary for consumer's and navigator's role models formation. The fourth group is communicative competences (skills of initiating communications and producing messages).

\section{References}

Aufenganger, S. (1999). Lernen mit den neuen Medien: Perspektiven für Erziehung und Unterricht. Medien-Generation: Beiträge zum 16. Kongress der Deutschen Gesellschaft für Erziehungswissenschaft. Opladen: Gogolin, Ingrid Lenzen.

Baran, S. J., \& Davis, D. K. (2012). Mass communication theory: Foundations, ferment, and future. Sixth ed. Boston (USA): Wadsworth.

Blau, P. M. (1994). Variety of opinions on social structure and their common denominator. In V.I. Dobrenkov (Ed.). American sociological idea: texts. Moscow: The Moscow University Press, pp. 8-29.

Bolts, N. (2011). Media alphabet. Moscow: Evropa.

Castels, M. (June 22, 2012). Our life is a hybrid of virtual and physical space. Retrieved from: //http://ria.ru/interview/20120622/ 679289114.html (access date 14.02.2015)

D'Inka, W. (2004). Journalism between public mission and market orientation. In E. Vartanova, Ya. N. Zassoursky (Eds). Shaping tomorrow's media systems. Moscow: Faculty of Journalism, Moscow State University, p. 61-73.

Druzhilov, S.A. (2012). The problems of higher professional education as symptoms of systemic crisis. Mezhdunarodny zhurnal eksperimentalnogo obrazovaniya, 10, p. 8-11.

Fateeva, I. A. (2008). Journalistic education in Russia: theory, history, modern practice (DLitt thesis). Ekaterinburg.

Frühbrodt, L. (2010). Journalistenausbildung an den Hochschulen. In G. Hooffacker (Hg.). Journalismus lehren. 10 Jahre Journalistenakademie. München: Verlag Dr. Gabriele Hooffacker, s. 35-46.

Homans, G. (1996). General propositions of exchange theory. In G.E. Zborovsky (Ed.). Anthology of modern western sociology of the second half of the 20th century. Ekaterinburg: Ural State Professional Teachers University, pp. 92-118.

Inkinen, S. (Ed.) (1999). Mediapolis: Aspects of texts, hypertexts and multimedial communication. Berlin; New York: Walter de Gruyter.

Jarvis, J. (2009). Who would buy a newspaper? Anybody? In Buzzmachine. Retrieved from: http://www.shirky.com/weblog/2009/03/: http://buzzmachine.com/2009/05/15/who-would-buy-a-newspaper-anybody.

Jaspers, K. (1991). History sources and its objective. Sense and designation of history (trans. from German). Moscow: Politizdat, pp. 28286.

Kasumova, E. V. (2014). Research of social competences of St. Petersburg schools leavers (by the example of media competences). Students - to the city. St. Petersburg: St. Petersburg Government, Committee on Science and Higher Education, pp. 80-88.

Korkonosenko, S. G. (Ed.) (2012). Modern Russian mediapolis. St. Petersburg: St. Petersburg State University, Philological Department. Luksha, P., Luksha, K., Peskov, D., \& Korichin, D. (2014). The atlas of new professions. Moscow.

Luhmann, N. (2005). Reality of mass media (A. Yu. Antonovsky, Trans.) Moscow: Praksis.

Mansurova, V. D. (2011). The "media" person of a Russian province: dynamics of social interaction. Barnaul: Altai University Press.

Masterman, L. (2001). A rationale for media education. In R. Kubey (Ed.). Media literacy in the information age: Current perspectives. New Jersey: Transaction Publishers, pp. 15-68.

Miroshnichenko, A. (February 28, 2011). What is to be done today, if newspapers die tomorrow? Retrieved from: http://www.forbes.r u/tehno-opinion/budushchee/64113-chto-delat-segodnya-esli-gazety-umrut-zavtra.

Piette, J., \& Giroux, L. (2001). The theoretical foundation of media education programs. In R. Kubey (Ed.). Media literacy in the information age: Current perspectives. New Jersey: Transaction Publishers, pp. 89-134.

Raspopova, S. S. (2007). Journalistic creativity: theory and practice of mastering (DLitt thesis). Moscow.

Rodgers, S., Barnett, C., \& Cochrane, A. (2008). Mediapolis: An introduction. In Mediapolis: Media practices and the political spaces of cities. Milton Keynes, UK: Open University, pp. 1-7.

Shesterkina, L. P. (2011). Formation of the innovation model of journalist training in the context of establishing convergent mass media (humanitarian and technologic aspects) (DLitt thesis). Moscow.

Shirky, C. Newspapers and thinking the unthinkable. Retrieved from: http://www.shirky.com/weblog/2009/03/.

Silverstone, R. (2007). Media and morality: On the rise of the mediapolis. Cambridge: Polity Press.

Volton, D. (2011). Information doesn't mean communication (Transl. from French). Moscow: POLPRED guides.

Wahl-Jorgensen, K., \& Hanitzsch, Th. (Eds.) (2009). Handbook of journalism studies. New York (USA): Routledge. 